\title{
WAYS OF EFFECTIVE DEVELOPMENT OF JOINT STOCK COMPANIES ON THE BASIS OF INNOVATIVE ACTIVITY
}

\author{
Shakirova Yulduz Saidalievna \\ Researcher of the Ferghana Politechnical Institute, 150100, Ferghana street 86, \\ Ferghana city, Uzbekistan
}

Article DOI: https://doi.org/10.36713/epra5281

\begin{abstract}
At a time when the world innovation management system was considered a strategic factor of economic development, conceptions and programs were adopted on the organization of infrastructure of innovative activities, development of organizational and economic context of innovative processes, improvement of management of innovation centers, development of innovation strategies of the region. However, in the practice of Innovation Management, little attention is paid to the development of organizational and economic management strategies for Innovation Management in the regions.
\end{abstract}

KEYWORDS: Innovative potential, modern problems, innovation potential management, innovation aims, resources.

\section{INTRODUCTION}

In the context of globalization, innovative development of industries and sectors is a priority in ensuring sustainable economic growth of the world and national economies. In economically developed countries, $70-90 \%$ of GDP is created due to the development of innovation. At the same time, they are achieving high development of the economy on the basis of modernization of leading industries, modern technical and technological renewal, introduction of local innovative technologies through the introduction of strategically important scientific and technological and promising innovative techniques and technologies, useful and profitable innovations.

\section{LITERATURE REVIEW}

Today, special attention is paid to scientific research on the organization of innovative activities and the improvement of effective development mechanisms in countries around the world. In this regard, the research on the support of innovative entities, targeted and effective development of the market of innovative products and the improvement of the mechanism of financing research projects of innovative entities play an important role. It should be noted that the application of effective mechanisms for the implementation of innovative activities in scientific research is considered a priority.

In the context of growing competition in the world economy, our country is taking consistent measures to build a modern, ie innovative form of economy. To this end, on the initiative of the President of the Republic of Uzbekistan Sh.M.Mirziyoev, a strong mechanism linking science and industry is being gradually developed.

The experience of industrialized countries shows that high innovative activity of the economy is ensured by the leading role of the state in the science and technology market, the definition of national priorities and the active influence of the state on the process of innovative development through economic incentives.

The priority strategic direction of innovative development of the economy of Uzbekistan is the establishment of a national innovation mechanism, which is a system of organizational, economic and legal measures and the implementation of certain innovative projects. It should ensure the process of production of new knowledge, rapid application of 


\section{EPRA International Journal of Research and Development (IJRD)}

research results to the real sector of the economy and the sale of new products to consumers.

In almost all modern economic theories, innovation is recognized as a source of development. Innovative potential is a separate key source of growth that ensures the development of not only an individual economic entity, but also the entire system.

The concept of "innovative potential" began to enter the science in the late $70 \mathrm{~s}$ of the twentieth century. It has been identified and developed in the methodological, theoretical research of a number of scientists. However, to date, no single universally accepted definition of this concept has been developed. Each scientist or specialist interprets the innovative potential in a specific direction, taking into account the characteristics of their country.

The absence of a universal innovation theory today has led to the emergence of many of its meanings and concepts. However, most approaches are based on the ideas of 'innovation' and 'change'.

Although many definitions of innovation emphasize the different characteristics of object innovation, the following selection serves to reflect the relevance of the nature of innovation.

One of the first economists to define the concept of innovation was Joseph Schumpeter. He used the terms "creative state" and "new combinations" and meant:

$>\quad \square$ production of a new product or improvement of product quality;

$>\quad \square$ creation of a new method of production;

$>\quad \square$ conquest of new markets;

$>\quad \square$ conquest of new markets for raw materials and semi-finished products;

$>\quad \square$ Implement organizational changes.

\section{DISCUSSION OF RESULTS}

The process of how to produce the innovations described by German innovation researchers Jürgen Hauschildt and Klaus Brockhoff plays an important role in gaining an understanding of the concept of innovation. It is especially important that Brockhoff distinguishes between the origin of the idea, the invention itself, and the processes that shape the production of a ready-to-sell product.

In the above steps, he described the concept of innovation in more detail, taking invention and product creation as the basis for understanding innovation. Each stage involves the decision-making process of accepting or rejecting an idea, its technological suitability, and the proposed economic achievement.
In this regard, the effective development of innovative activities is of paramount importance, and the competitiveness of industrial enterprises of the republic in both domestic and foreign markets depends on the efficiency and effectiveness of its activities.

In order to increase the innovative activity of industrial enterprises of the republic, it is necessary to form a balance between all components and links of the innovation cycle. One of such directions is the creation of mechanisms of interaction of the subjects directly carrying out or participating in innovative activity in production process.

This creates the need for the effective formation of innovative activity in industrial enterprises and the creation of conditions for its development. Systematization of foreign experience in the formation and development of innovative activities allows to identify the basic aspects of the creation of some of its elements and identify opportunities for their use in the national economy.

One of the most promising foreign experiences and directions in terms of the development of innovative activities is the use of models involving the private sector and research organizations. These models ensure the distribution of investment risks and savings of public funds in the organization of innovative activities.

In our opinion, the mechanism for the development of innovative activities should be based on the following principles:

- Ensuring consistent communication between existing research institutions, industrial enterprises and credit and financial organizations;

- creation of a mechanism to ensure coordination and sustainable interaction in the implementation of innovative activities in industrial enterprises;

- the need to determine the long-term prospects for innovative development of industrial enterprises;

- Adaptation to the changing external and internal environment and focus on the end result in the implementation of innovative activities of industrial enterprises.

The analysis of the existing problems of innovative activity in the enterprises of the coal industry of the republic shows that the current situation does not fully meet the needs of enterprises today. This requires the improvement of the infrastructure support system, which will create favorable conditions for innovative activities. 


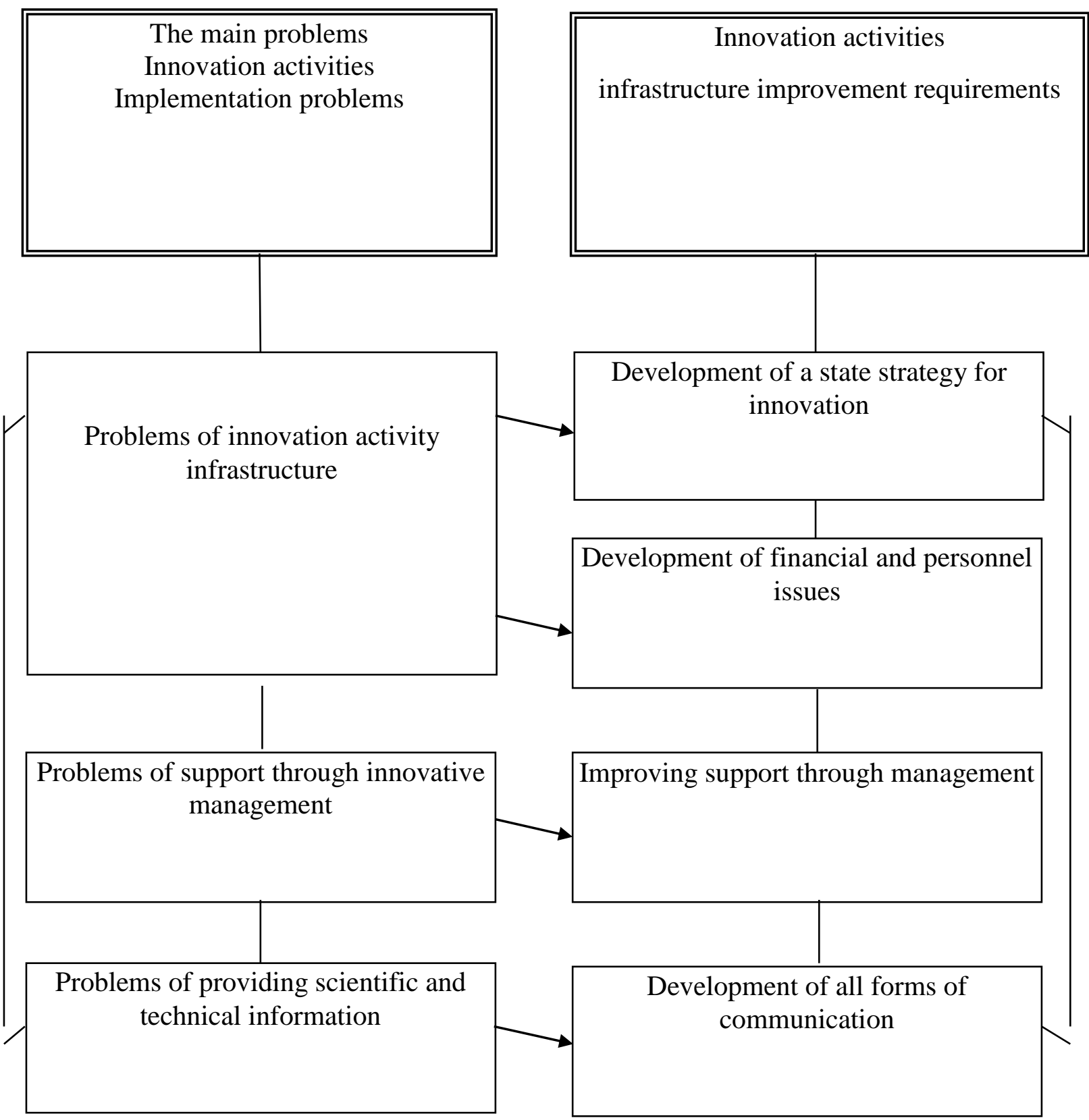

Figure 1. The system of links between the development and improvement of innovative activities

The analysis shows that despite the scale of work on further improving the efficiency of innovative activities in industrial enterprises of the country, the introduction of innovative technologies and developments in industries and sectors, today fully mobilizes all material, technical, scientific and intellectual resources. the potential is not fully used. This, in turn, requires further improvement of specific mechanisms that ensure innovative activity between producers and consumers of scientific products in enterprises and full adaptation of these mechanisms to the pace of economic and sociopolitical reforms in the country.

In our opinion, the definition of innovative activity as an economic category should reflect the following aspects:

- a set of processes of production and nonproduction nature, providing continuous improvement as a result of the development of science and technology, the growth of the 


\section{EPRA International Journal of Research and Development (IJRD)

needs of the population and society on the basis of objective economic laws and regulations;

- Opportunities to use the innovative potential needed to create, commercialize and put into practice new products with a new quality of production.

The results of our research show that the development of mutual cooperation between the subjects of innovative activity, programs that allow to increase the effectiveness of cooperation, is an objective necessity.

Along with the existing opportunities, in order to further develop innovative activities in the country, the state must: create a favorable business environment that focuses on private initiative to innovative research; establishment of a venture financing mechanism: assistance in developing the infrastructure of innovative activities at the micro, meso and regional levels (insurance, institute of innovative intermediaries, technoparks, etc.).

In the process of solving these tasks, private entrepreneurs and producers will have the opportunity to move from the traditional model of business organization to an innovative model.
World experience shows that one of the most effective ways to develop the economy innovatively and increase its competitiveness is the integration of partners and subsidiaries of a particular industry, all participants in the value chain.

The organization and implementation of the process of modernization of modern production in industrial enterprises necessitates the identification and evaluation of innovative activity and its potential. Infrastructure that effectively influences the innovation sector is an important factor that ensures the assimilation of advanced technology and economic adaptation to its procedure, based on various - district, complex and long-term interaction between the market and the innovation sector. To some extent, the competition mechanism ensures the intensity (speed) of innovation processes.

The share of exports of innovative products in total exports is only $1.46 \%$. It should be noted that in developed countries, $70-90 \%$ of GDP is accounted for by the development of innovation.

Because the innovative potential of an industrial enterprise is formed on the basis of a large number of different factors, it is difficult to determine its generalized level and value. ${ }^{1}$
${ }^{1}$ Uzbekistan Republic state of statistic Declaration official statistician Informatics, long and periodic publishing declamation fundamental analysis. 


\section{EPRA International Journal of Research and Development (IJRD)}

Table 1

Dynamics of important indicators of development of innovation activity (industry) in Uzbekistan in 2012-2018

\begin{tabular}{|c|c|c|c|c|c|c|c|c|c|}
\hline \multirow{2}{*}{ № } & \multirow{2}{*}{ Indicators } & \multicolumn{2}{|c|}{2012} & \multicolumn{2}{|c|}{2014} & \multicolumn{2}{|c|}{2016 й. } & \multicolumn{2}{|c|}{2018 й. } \\
\hline & & total & industry & total & industry & total & industry & total & industry \\
\hline 1. & $\begin{array}{l}\text { The share of innovative products } \\
\text { in total sales, } \%\end{array}$ & 2,9 & 4,5 & 3,2 & 3,9 & 5,8 & 8,4 & 6,5 & 8,4 \\
\hline 2. & $\begin{array}{c}\text { Growth rate of sales of } \\
\text { innovative goods, works and } \\
\text { services, } \%\end{array}$ & 100 & 100 & 62,3 & 54,6 & 126,4 & 130,7 & 116,4 & 125,4 \\
\hline 3. & $\begin{array}{c}\text { The share of own funds of } \\
\text { organizations in the total cost of } \\
\text { innovations, } \%\end{array}$ & 60,5 & 74,9 & 70,6 & 75,2 & 68,4 & 54,0 & 36,8 & 31,0 \\
\hline 4. & Cost ratio for innovations & 0,014 & 0,012 & 0,005 & 0,004 & 0,003 & 0,005 & 0,026 & 0,043 \\
\hline 5. & $\begin{array}{l}\text { Rate of growth of expenditures } \\
\text { for innovations, } \%\end{array}$ & 100 & 100 & 121,4 & 63,8 & 73,0 & 122,4 & 72,0 & 91,1 \\
\hline 6. & $\begin{array}{c}\text { Share of innovative active } \\
\text { enterprises }\end{array}$ & 0,13 & 0,37 & 0,07 & 0,25 & 0,07 & 0,23 & 0,35 & 1,29 \\
\hline 7. & $\begin{array}{l}\text { The number of technological } \\
\text { innovations introduced, } \\
\text { corresponding to the } \\
\text { contribution of each innovative } \\
\text { active enterprise }\end{array}$ & 2,2 & 3,5 & 4,4 & 3,5 & 3,8 & 3,9 & 1,7 & 1,6 \\
\hline 8. & $\begin{array}{c}\text { University-Company } \\
\text { Level of cooperation in research }\end{array}$ & 25,5 & 15,5 & 15,8 & 19,3 & 8,8 & 16,3 & 9,2 & 4,5 \\
\hline
\end{tabular}

It is not an assessment of the dynamics of individual factors affecting innovation potential in industrial enterprises, but the identification of changes in the general trends of innovation potential through a cumulative index. In our opinion, one of the most convenient methods in assessing the level of innovative potential of the enterprise is the expert evaluation method (including scoring method), and analyzes show that it is usually evaluated by relative indicators - indices and average performance methods.

\section{CONCLUSION}

The generalized indicators of the level of innovation potential determined by the cumulative index are calculated as the average value of the average indices in each group. This makes it possible to determine the different objective effects of selected conditional indicators on innovation potential in different directions.

Effective development of innovative activities in the coal industry of the national economy should be based on the following successive stages: creation of favorable conditions in the industry implementation of effective and efficient research organization of financial and investment support consulting and expertise - building infrastructure commercialization. Each step requires that it be carried out on the basis of specific measures aimed at ensuring its implementation.

\section{LIST OF USED LITERATURE}

1. Аиуров, М.С., Шакирова, Ю.С. Вопросы устойчивого развития промышленных предприятий Узбекистана в условиях риска. // Проблемы современной науки и образования. 2019. № 4 (137), C. 32-37.

2. Шакирова, Ю.С. Анализ факторов влияюших на неформальную занятость в Узбекистане. ЭКОНОМИКА И БИЗНЕС: теория $u$ практика, 11-3 (57), 2019. 173-180. DOI: https://doi.org/10.24411/2411-0450-2019-11418

3. Шакирова, Ю.С. Пути развития корпоративного управления в Республике Узбекистан. //Наука и образование сегодня, 2019.№5 (40), C. 51-54.

4. Ашуров, М.С., Шакирова, Ю.С., Турдибеков, О. И. Тенденции формирования многоукладной экономики в Узбекистане. Бюллетень науки и практики, 5 №12, 2019, 305-311. Doi: https://doi.org/10.33619/2414$\underline{2948 / 49 / 35}$

5. Ханкелдиева Г. Ш. Особенности корпоративного управления в акционерных обществах с государственным участием // Бюллетень науки и практики. Электрон. журн. 2017. №11 (24). С. 357-363. Режим docmyna:

http://www.bulletennauki.com/honkeldiyeva (дата обращения 15.11.2017).

6. Ханкелдиева Г. Ш. Перспективы развития электроэнергетической отрасли Республики Узбекистан в условиях модернизации экономических отнотений // Бюллетень науки 


\section{EPRA International Journal of Research and Development (IJRD)

и практики. Электрон. журн. 2017. №12 (25). C. 293-299. Режим доступа: http://www.bulletennauki.com/honkeldiyeva-g (дата обращения 15.12.2017).

7. Khankeldieva G.Sh. Theoretical and Economic Prerequisites for the Development of Regional Industrial Clusters in the Economy of the Republic of Uzbekistan // EPRA International Journal of Research and Development (IJRD). 2020. pp. 234-240. https://doi.org/10.36713/epra $\underline{4855}$

8. Khankeldieva G.Sh. Prospects of the development of investment activity in the field of tourist services: problems and ways of solution // Theoretical \& Applied Science, Philadelphia, USA. 10, (78), 2019. 160-165 pp.

9. Abdullayev, A. M., Kurpayanidi, K.I. (2020) Analysis of industrial enterprise management systems: essence, methodology and problems. Journal of Critical Reviews, 7 (14), 1254-1260. Doi: http://dx.doi.org/10.31838/jcr.07.14.261

10. Kurpayanidi, K. I., Abdullaev, A. M., \& Khudaykulov, A. (2020). Challenges of coping with the economic consequences of the global pandemic COVID-19. ISJ Theoretical \& Applied Science, 05 (85), 1-5. Doi: https://dx.doi.org/10.15863/TAS.2020.05.85.1

11. Kurpayanidi, K. I., Abdullaev, A.M., Nabieva, N.M., Muminova, E.A., Honkeldieva, G.Sh. (2020). Economic and Social Policies During Covid-19 Period:Relief Plan of Uzbekistan. International Journal of Advanced Science and Technology, 29(06), 5910 - 5921. Retrieved from http://sersc.org/journals/index.php/IJAST/article/ view/19871

12. Kurpayanidi, K., Abdullaev, A., Ashurov, M., Tukhtasinova, M., \& Shakirova, Y. (2020). The issue of a competitive national innovative system formation in Uzbekistan. In E3S Web of Conferences (Vol. 159, p. 04024). EDP Sciences. Doi:

https://doi.org/10.1051/e3sconf/202015904024

13. Margianti, E. S., Ikramov, M.A., Abdullaev, A.M., Kurpayanidi, K.I., Misdiyono, M. Role of goal orientation as a predictor of social capital: Practical suggestions for the development of team cohesiveness in SME's. Gunadarma Pulisher, Indonesia. Doi: http://dx.doi.org/10.13140/RG.2.2.28953.44641

14. Курпаяниди, К. И., \& Ашуров, М. С. (2019). Ўзбекистонда тадбиркорлик мухитининг замонавий хуолати ва уни самарали ривожлантириш муаммоларини бахолаш. Монография. GlobeEdit Academic Publishing, European Union. Doi: http://dx.doi.org/10.13140/RG.2.2.34273.74088

15. Курпаяниди, К.И., Ашуров, М.С. (2020) COVID-19 пандемия шароитида тадбиркорлик ва уни ривожлантириш масалалари: назария ва амалиёт. GlobeEdit Academic Publishing, European Union. Doi: https://doi.org/10.5281/zenodo.4046090
16. Kurpayanidi, K. I. (2020) About some questions of classification of institutional conditions determining the structure of doing business in Uzbekistan. South Asian Journal of Marketing \& Management Research, 5(10), 17-285. South Asian Academic Research Journals, Doi: http://dx.doi.org/10.5958/2249877X.2020.00029.6 